\title{
An Understanding of Performance: THE BEATLES IN HAMBURG
}

\author{
Ian Inglis
}

Becoming a musician is something that has to be learned. I refer here not only to mastery of the requisite technical skills, but to the demands, obligations and conventions that govern professional behaviour. And what lies at the heart of an occupational musician's life is performance. The idea of serving an apprenticeship, of learning to be a performer, of gradually coming to understand the craft of performance, has always been central to the act of music-making. And I want to use the example of the Beatles in Hamburg to illustrate how this might take place, indeed, how it did take place for them.

In fact, the significance of performance in assessments of popular music has been consistently noted by academics and musicians alike. Avron White has argued that

»although the musical product yields its greatest source of income in recorded and written form, its authenticity, or validity, is very much dependent upon the music's being on view in the live performance. In this context, the musical product is produced and consumed in the same moment: there is an inextricable association between the musician and his music (White 1987: 187).

And guitarist Jeff Beck explains:

»Most people have never heard me get the best out of a guitar. Recording puts a barrier between the artist and the audience. Records never have, never will, show my true potential. I only get the feeling I'm putting my true self across when performing live« (Beck in Martin 1983: 143).

However, what is actually meant by >live performance< can occasionally be a little misleading, as numerous examples confirm. In the 1960s, television shows billing themselves as >live. (Top Of The Pops, Ready Steady Go) routinely presented groups or singers who were clearly miming to various combinations of pre-recorded vocal and/or instrumental tracks: here, live. 
often referred to the time of the broadcast, not to the musical content. The popularity of >live albums from the late 1960s and 1970s obliged such recordings to undergo scrupulous editing, splicing, cleaning and studio enhancement in order to produce what the industry saw as a commercially acceptable product - with the result that what was heard on the subsequent album often bore little resemblance to what was actually heard by the audience in the original venue. In 1999, the British boy-girl band Steps were voted >Best Live Act < by the readers of TV Hits magazine, despite the well-known fact that music and vocal tracks at all their concerts were prerecorded in order to allow the five band members to concentrate on the energetic dancing, mini-narratives, prolonged audience interaction and frequent costume changes that distinguished their performance. Perhaps the most notorious example of >false liveness < was provided by the career of Milli Vanilli, who successfully masqueraded as live performers and recording artists until they were found out in 1990.

Sometimes, the artifice can become part of the attraction. In 1997, the Elvis Presley In Concert production premiered in Memphis, and has since gone on to tour the world. Undeterred by the fact of Presley's death in 1977, the concerts combine film footage of the singer with live musical accompaniment. The show's promotional material announces:

»The Elvis footage is projected on a large video screen. On stage a 16-piece orchestra and some of Elvis' original bandmates from the concert era of his career and other cast members perform live with the Elvis video. [...] From the first song it's magic. You're at a real Elvis concert. Elvis' recorded voice and his on-screen presence are so powerful, the interaction with the live musicians and singers so seamless, the audience reaction so intense that, a few songs into the show, one can almost forget that Elvis isn't really there in person. Everything in terms of staging, set design, lighting, sound, and overall production is as if Elvis were alive and back out on the road. [...] The production is so authentic and so well done that there are moments in the show when even Elvis' own bandmates and members of the production team think Elvis is really back in the building!« (http://www.elvis.com/events/ concert_tours.aspx; accessed 21.9.2012).

The efficient combination of live and non-live performance has not been limited to those who have died. Recent James Taylor concerts have included a segment in which he sings live on stage to the accompaniment of a filmed choir projected on a large screen behind him; furthermore, just as in the Elvis Presley show, the smiles, mutual glances and acknowledgements between Taylor and the choir are so well-rehearsed as to make the spectacle utterly convincing. More bizarrely, in Japan, the career of Hat- 
sune Miku (including sell-out concerts and chart-topping songs) has not been hindered by the fact that she is a computer generated cartoon character with a synthesised voice. Her live appearances consist of a three-dimensional holographic image of the singer performing energetically on stage. And Yamaha's Vocaloid programme has enabled her creators to invent a realistic - albeit entirely synthesised - singing voice. Indeed, it seems there are few limits to such technological input, especially in Japan: in June 2011, it was revealed that Aimi Eguchi (of the girl band AKB48) was, in fact, a CGI creation whose facial features were a composite of the other (real) band members.

What all these examples demonstrate is that across many contexts the television programme, the album, the arena concert, even in the public presentation of performers - >live< may not always mean >live<. But for the majority of musicians and audiences, particularly for those gigging bands in the early stages of their career, a live performance continues to represent an encounter between the producers and consumers of music, that carries with it ideological notions of authenticity, truth, excitement, energy and direct contact that may be lost elsewhere. Yet such encounters are never straightforward. Performances are multi-layered phenomena. Every performance is mediated by time, space, location, the number of participants, the acoustic environment, and so on. In this sense, performance can be both a shared activity and a confrontation, in which performers and audiences have to learn certain skills, and understand certain conventions, in order for it to proceed. Jason Toynbee has described this comingtogether as constituting the theatrical side of performance $<$ :

»the way that music-making is staged as something performed by musicians for an audience [...] music is not only being made, but being made to be heard, and sometimes to be seen too. The theatricality of popular music performance derives from performers conceiving themselves as performers, and audience members thinking that they are members of an audience« (Toynbee 2000: 57).

In order to expand and illuminate these issues, I want to use the experiences of the Beatles in Hamburg in 1960-1962 to consider how live performance may be approached, learned and understood, and to illustrate the ways in which such an understanding impacted on the group's career. To recap on the history very briefly, the Beatles made five separate visits to the city. On their first visit, arranged by Liverpool promoter Allan Williams, from August through to November 1960, they spent seven weeks at the Indra before moving for a further eight weeks to the Kaiserkeller, both of 
which were owned by Bruno Koschmider. In 1961, they spent the whole of April, May and June at Peter Eckhorn's Top Ten Club. And in 1962, they played three separate engagements at Manfred Weißleder's newly-opened Star-Club: seven weeks in April and May, two weeks in November, two weeks in December. All four clubs were in the St. Pauli area of the city, either on the Reeperbahn or just off it on Große Freiheit. Interestingly, the total time they spent on stage was an estimated 800 hours over 273 nights across 29 months: an almost identical figure to the 274 appearances across 30 months they made at The Cavern in Liverpool between February 1961 and August 1963. And yet it is The Cavern, rather than Hamburg, that has successfully claimed for itself the title of sthe birthplace of the Beatles .

When they set out on their first trip, there were five Beatles: John Lennon, Paul McCartney, George Harrison, drummer Pete Best and bass guitarist Stuart Sutcliffe. By the time of their final visit, Best had been replaced by Ringo Starr, Sutcliffe had quit the group and subsequently died in Hamburg. During that two-and-a-half-year period, the group also acquired a new manager (Brian Epstein), secured a recording contract with Parlophone, and released its first single »Love Me Do « in the UK. It is a period in the group's history that has been subjected to an enormous amount of hyperbole, sensationalism, reconstruction and misrepresentation. Two movies - Birth Of The Beatles (Richard Marquand, 1979) and Backbeat (lain Softley, 1994) - have added to its notoriety by presenting accounts of the group's years there that are steeped in the stereotyped ethic of ssex and drugs and rock'n'roll<. In addition, the vast majority of biographies of the Beatles, or of the individual members, contain a section or chapter just labelled >Hamburg . But few of them have anything new to say about the Beatles in Hamburg. They tend instead to relate the same stories, to quote the same voices, to rely on the same explanations. Early in my research, I was warned by Tony Sheridan (who was one of the leading figures in the Hamburg club scene of the early 1960s, and who still lives in Germany) to be very wary of the versions offered by those professional commentators of the story - the self-styled insiders, whose exaggerations, particularly concerning their own role in the history of the Beatles, are motivated much more by ideas of self-aggrandizement or financial reward, than by a desire to relate a historically accurate record of events. He told me: »Beware of the unqualified utterances of certain sexperts < [...] much of the piffle these guys relate should be taken with a large pinch of salt « (Sheridan, personal communication, 2011).

With this in mind, it thus becomes sensible to emphasise the accounts offered by the Beatles (and their fellow musicians) themselves. And what 
such accounts reveal is a clear pattern in which two recurring characteristic features are prominent. The first is that all the Beatles regarded Hamburg not Liverpool - as the place where they developed their abilities as performers. There was no doubt about this.

George Harrison: »Hamburg was really like our apprenticeship, learning how to play in front of people« (Harrison in Beatles 2000: 49).

John Lennon: »It was Hamburg [...] that's where we really developed. We would never have developed as much if we'd stayed at home« (Lennon in Davies 1968: 105).

Pete Best: »That's when the charisma really started to grow « (Best in Giuliano/Giuliano 1995: 207).

Paul McCartney: »We went to Hamburg, nothing happened to start with, then we were IT!« (McCartney in Coleman 1995: 61).

And in a letter written to his sister Pauline, Stuart Sutcliffe claimed that »we have improved a thousandfold since our arrival « (Sutcliffe/Thompson 2001: 92).

The second is that there is rarely any attempt to offer a close analysis of what it actually was about the Beatles' experiences in Hamburg venues that produced these effects. There are, of course, plentiful references to the long hours they were forced to play, and the cramped conditions in which they were forced to live, but there is often very little beyond that. It therefore becomes important to consider these claims of rapid and startling improvement, not just in themselves, but within the context of the time and place in which they took place - Hamburg, in the early 1960s - to try to understand the nature of the Beatles' performances in the city, the constraints under which they were obliged to perform, the opportunities that these presented, and how and why the various components came together to help transform an unremarkable, semi-professional group of teenagers into popular music's most celebrated and influential performers in little more than two years. And it bears repeating that a key element in any such evaluation is the notion of >authenticity<, or >truth . While it is a concept a highly contested concept - that continues to permeate popular music, it was particularly relevant at the time. Sarah Thornton has noted that:

»While authenticity is attributed to many different sounds, between the mid50 s and the mid-80s, its main site was the live gig. In this period, >liveness dominated notions of authenticity [...] the essence or truth of music was located in its performance by musicians in front of an audience« (Thornton 1995: 26). 
When the Beatles arrived in Hamburg, they had next to nothing in the way of performance experience. They had yet to appear at The Cavern, their gigs in Liverpool had been fairly infrequent, and often limited to suburban dancehalls or local institutes, and social functions such as birthdays and wedding parties. They seldom rehearsed, they had been without a permanent drummer for some time, they had no sact - to speak of, no stage routines, and music was a part-time activity - all were at college, or school, or in fairly unrewarding jobs. As is well known, when Liverpool group Derry \& The Seniors (who were already in Hamburg) learned that the Beatles would be joining them, they wrote back in alarm to Williams, pleading with him not to spoil it for them by sending over »a bum group like the Beatles« (Williams/Marshall 1975: 129-130).

Their debut, in the Indra, on the evening of Wednesday $17^{\text {th }}$ August 1960 was not a huge success. The group's one attempt to construct a more impressive stage presence was to wear a matching uniform, in classic British teddy-boy style, of lilac velvet jackets, black shirts, black jeans, and winkle-picker shoes. However, this meant little to the Hamburg audience, whose participation and membership of youth subcultures was quite different to the UK, and was centred around two major groups. One was the >rockers w who adopted the leather jackets and blue jeans fashion of Marlon Brando in The Wild One (László Benedek, 1953) or, more likely in the German context, Horst Buchholz in Die Halbstarken (Georg Tressler, 1956) or Teenage Wolfpack as it was re-titled in the UK and the US. The other group, derived to a considerable extent from Hamburg's large student population, were the >exis<, or existentialists, named after the Left Bank intellectuals of Paris, whose preferred appearance was a pseudo->Bohemian style of casual, disorderly hair and clothes.

Either way, the Beatles' appearance emphasised the cultural distance between the group and its audiences. Furthermore, Sutcliffe's lack of musicianship (he could barely play the guitar) and Best's unfamiliarity with the group's repertoire (he had joined just a few days before they left Liverpool) resulted in a turgid and plodding performance that dismayed Koschmider and attracted very few customers.

It was at this point, after several uninspired evening shows, that Koschmider instructed the Beatles to liven things up, to inject some energy into their performance: »Macht Schau!«, literally to sput on a show<. He had brought the Beatles to Hamburg not because he admired their music (he had never actually heard them) nor to promote them as a commercial act, but because he believed that the presence of a live group - any live group could be a successful device to attract customers into his clubs, where they 
would then stay to spend money on drinks, rather than go to other bars in the area. In fact, very few of the potential customers around the Reeperbahn and Große Freiheit had come out to listen to music. Many of them were visiting tourists and sailors, who swarmed into St. Pauli every evening to visit its strip-clubs, brothels and bars, helped along by large quantities of alcohol. Fifty years earlier, in the first decade of the twentieth century, Hamburg had been the third largest port in the world (after London and New York). Despite the loss of trade that followed Germany's defeat in the First World War, and the bomb damage inflicted during the Second World War (when 80 per cent of the port was destroyed) it had by 1960 recovered much of its prosperity and, with a surrounding population of two million residents, was Germany's second city, and one of Europe's largest ports. And its large transient population of sailors, traders and visitors were keen to explore the Reeperbahn's reputation for raucous entertainment which, like Soho in London or the red-light district of Amsterdam, was built largely around the sex industry.

In this sense, the injunction to »Macht Schau « had no musical relevance at all. And once the Beatles realised that they were simply there to promote the club, rather than to be heard, their approach changed. As Paul McCartney later testified, it was a major insight in their apprenticeship:

»We had to attract people in. The first thing people would look at was the beer price [...] then they'd look around and there'd be no-one in the club, and we'd jump into action: >Yes! Yes! This is the night! Come on in! You really have to learn that... and we learned it« (McCartney in Miles 1997: 58).

In effect, the Beatles realised that they were not expected to be musicians but to be entertainers, performing the same function as barkers at a fairground: and with that realisation, their perception of their collective identity began to shift - not only in terms of how they were evaluated by others, but also by themselves. Given these new requirements, Lennon was the first to deliberately exploit the physical dimension of rock'n'roll, and his rapid abandonment of any inhibitions about what could, and could not, be done on stage was quickly followed by the rest of the group. The original static delivery of two- or three-minute songs was replaced by five- or tenminute numbers in which the Beatles would dance or strut from one side of the platform to the other, throw themselves around, race on and off stage, and - instead of merely announcing the title of each song - shout and scream at the customers above the noise.

It was this physicality - not the quality - of their music that helped to ensure the group's initial success and popularity in Hamburg. It may not be a 
surprising observation. Before and after the Beatles (in the 1950s, the hostile reaction to Elvis Presley, nicknamed Elvis the Pelvis in the US and filmed on US TV only from the waist up because of his swinging hips; in the 1980s, the impact of Michael Jackson's >moonwalk<) many of popular music's biggest stars have been noted as much for their onstage movements as for their music. But at the time, it was a factor the Beatles had not previously addressed. Nor, it has to be said, had they considered the nature of the audience response, which in the case of Hamburg could be positive (sending up crates of beer to the group, or leaping on stage to perform with them) or negative (catcalling, throwing things, or issuing physical threats). Photographer Jürgen Vollmer, who met the group shortly after they'd moved to the Kaiserkeller, has said:

"I can't imagine that they could be any better than they were in Hamburg, any more energetic, any more giving it all. There were a lot of fights. There wasn't an evening where I wasn't afraid. But the Beatles got used to it« (Vollmer in Sharp 2000: 41-42).

Historically, such circumstances were not new. Indeed, descriptions of events and conditions within the Reeperbahn's clubs are uncannily like those of London's music halls in the mid-nineteenth century, as Peter Jackson has described:

»Competition was fierce, innovation intense, and the pace of change extremely rapid. [...] The audience was free to smoke and drink, eat and talk, even at the height of the performance. Audiences engaged in an active dialogue with the players. They expressed their approval or disapproval with gusto, pelting the performers with whatever they had to hand « (Jackson 1989: 86-87).

When the Beatles returned to Liverpool in December of 1960, one of their first bookings was at Litherland Town Hall - a date that has often been described as the »catalyst for the whole phenomenon of beat music in Liverpool « (Gould 2007: 89). John Lennon saw it as »the evening when we really came out of our shell and let go. This was when we began to think for the first time that we were good. Up to Hamburg, we'd thought we were OK, but not good enough « (Lennon in Davies 1968: 104). Without exception, all of the contemporary commentaries on that show concentrated on its performative aspect: either on the Beatles' appearance - no longer dressed in Teddy boy outfits, but leather jackets, black T-shirts, skintight pants and cowboy boots bought at the Texas shop in Hamburg (Spitz 2005: 10-11), or on the animated manner in which they delivered their music, which according to Liverpool promoter Sam Leach had the crowd »rooted to the spot: everybody was watching, rather than dancing « (Leach 1999: 46). It 
was what they had learned over their initial three or four months in Hamburg - that instinctive and unrestrained interaction with the rowdy, volatile crowd helped to create the right conditions in which to perform their music - that distinguished them from their competitors. And, as a footnote, it was the enthusiastic local response to this, and other appearances in December and January, that led to the Beatles securing their first engagement at The Cavern, just a few weeks later, in February 1961.

My comments thus far have referred to the form or delivery of the music. It is equally important to consider the content or nature of the songs performed by the Beatles in Hamburg. Inasmuch as he expressed any musical policy, Koschmider wanted the musicians he employed to re-create the sounds of American rock'n'roll. In Germany, there were two prevalent varieties of domestic popular music to be heard in the late 1950s and early 1960s: Schlager, which was light, sentimental, middle-of-the-road pop performed by singers such as Peter Alexander and Freddy Quinn (>the Singing Sailor<); and German rock'n'roll, essentially a milder imitation of its American counterpart, whose principal performers included Peter Kraus and Ted Herold (>the German Elvis<). However, neither form generated great enthusiasm among the young local audiences, who clearly preferred their limited opportunities (the jukebox, the radio) to hear American styles. Moreover, German audiences were relatively unfamiliar with the four-piece template of lead guitar, bass guitar, rhythm guitar and drums that was becoming the norm in the UK; their preference was still for the solo performer. The task of the Beatles during their engagements in Hamburg was therefore very simple: to create, as a group, a live musical experience whose sounds would match the excitement of those coming from the jukebox. And rock'n'roll, with its connotations (real or imagined) of disobedience, rebellion, anti-authoritarianism and delinquency, was the ideal vehicle through which to set about it.

And initially, this is what the Beatles provided: unashamed cover versions of US rock'n'roll, including songs by Elvis Presley, Gene Vincent, Eddie Cochran, the Del Vikings, Fats Domino, Bill Haley, Jerry Lee Lewis, The Olympics, Buddy Holly, Lloyd Price, Little Richard, The Coasters (and occasional instrumental covers of tracks by Duane Eddy \& The Ventures). This in itself was unsurprising. With very few exceptions, rock'n'roll in the UK followed the conventions, and celebrated the performers, of US rock'n'roll: and those American songs the group covered were the sounds that had originally inspired them. Moreover, this policy was perfectly appropriate for the half-hour sets the Beatles were used to playing in Liverpool: it gave them a more than adequate number of songs from which they could select a 
suitable repertoire. However, when they found in Hamburg that they were expected to perform for up to six hours per night, every night, they quickly realised that their stock of songs would be rapidly exhausted.

There were several solutions to this. First, the group continued to search out and incorporate a large number of additional rock'n'roll tracks, particularly by black musicians such as Chuck Berry, Larry Williams and Ray Charles. Secondly, they began to feature numerous songs composed by the Brill Building's teams of writers, particularly Gerry Goffin \& Carole King, and Burt Bacharach \& Hal David: indeed, Lennon and McCartney have both stated that their early ambition was to be »the Goffin and King of England « (Lennon in Sheff/Golson 1981: 146). A third, related, strategy employed by the Beatles in Hamburg was their adaptation of records by US girl groups or solo female performers: this was especially significant, because by disregarding stereotypical gender divisions between >male songs a and >female songs<, the group gained access to a much wider range of material than many of its more reluctant competitors and, crucially, introduced a 'woman's viewpoint < into their music. Fourthly, the Beatles increased the number of romantic ballads, many of which were established standards<, in their live repertoire, featuring songs by Bing Crosby, Peggy Lee, Dorothy Lamour, Marlene Dietrich, Dinah Washington and Judy Garland. Fifthly, they became increasingly aware of composers and performers on Detroit's TamlaMotown label after its formation by Berry Gordy in January 1959, and added early songs by The Marvelettes, The Miracles, Barrett Strong and The Isley Brothers to their roster.

In all of these, the Beatles did not just copy what they heard, but changed it: either lyrically, musically or in performance: as Lennon explained: swe would take our favourite records and then we would make better versions of them (Lennon in Leigh 2004: 77). The contrast between "Twist And Shout « as recorded by the Top Notes, and then by the Isley Brothers, and the version by the Beatles is perhaps the best indicator of this strategy. And by transforming, rather then merely imitating, someone else's record, the Beatles were thus taking the first steps towards asserting an independent musical identity that was not only professionally advantageous, but also personally satisfying. The Beatles were not alone in this. One of the most popular songs in the clubs of Liverpool and Hamburg was Ritchie Barrett's »Some Other Guy«. John McNally of the Searchers, who also spent significant amounts of time in Hamburg in 1962 and 1963 has explained:

»The Beatles did `Some Other Guy<. We did `Some Other Guy`. The Big Three did `Some Other Guy`. Everybody did `Some Other Guy`. But, if you listen to 
all the versions of 'Some Other Guy<, or >Money<, you'll find that no two versions are the same« (McNally in Brocken 1996: 30).

A related facet of these strategies for the Beatles was their reliance on three lead vocalists. This was a pragmatic as well as a democratic decision. Switching singing responsibilities within the group helped to avoid the possibilities of vocal strain or exhaustion that would have followed from having just one lead singer performing for several hours every night. Thus, the combination of an extensive and unusually broad musical catalogue, and an egalitarian musical structure built around three focal points of attention, immediately set the group apart from its rivals in Hamburg, the majority of whom relied on just one lead singer: Rory Storm \& The Hurricanes, Gerry (Marsden) \& The Pacemakers, and so on.

But, the most important way in which the Beatles increased their repertoire to cope with these new demands was that they decided to write more songs themselves. Lennon and McCartney had (either alone or together) already written a small number of songs before the group went to Hamburg, including early versions of »Hello Little Girl«, »Love Of The Loved«, »Like Dreamers Do« and »One After 909 «. There were probably no more than twenty or thirty of these (several of which were incomplete, and some of which were instrumentals). Conscious of the need to attract customers through familiar songs, and unsure of the audience reaction to unfamiliar material, the group initially tended to limit its own compositions to very occasional performances. However, again, faced with a daily requirement to deliver several hours of live music, and knowing that the possession and presentation of their own songs gave them a real advantage over their competitors, the Beatles gradually began to increase their inclusion.

Because they were driven by an obligation to fill the group's stage-time, rather than by a desire for personal expression, the early compositions of Lennon and McCartney were relatively simple, often derivative and lyrically straightforward.

Crucially, the songs were written not with recording in mind, but to be performed live, onstage, by the Beatles, with nothing more than guitars and a drum kit. But, as composing took up increasing amounts of their time through 1960-1962, many of the songs they wrote were deemed good enough to become regular fixtures in their live shows in Hamburg. Over the next few years, as their songwriting skills developed and their career accelerated, self-compositions would provide the vast majority of their live and recorded output. But, throughout its career, the sources to which the group had turned for additional material in Hamburg continued to inform 
their own songwriting sensibilities. Thus, tracks like »I'm Down«, »Lady Madonna « and "Get Back« reproduce the sounds and rhythms of 1950s rock'n'roll. The influence of the Brill Building is clear on songs such as »Do You Want To Know A Secret«, »Hold Me Tight « and »You Won't See Me«. »You're Going To Lose That Girl«, »Tell Me Why« and »All I've Got To Do« echo, very precisely, both the musical form and lyrical content of many of the early 1960s girl groups records. The tradition of romantic ballads inspired »Yesterday«, "Something « and »Goodnight«. And Motown is the driving force behind »Ask Me Why«, »Got To Get You Into My Life« and »This Boy«.

But the part that Hamburg played in the emerging Lennon-McCartney songwriting partnership was not just a consequence of the hours spent on stage. Their living quarters provided a concentrated, even claustrophobic, environment in which musical discussion, comparison, and competition proceeded on a daily basis. In Liverpool, the four or five Beatles lived at their own homes, seeing each other irregularly. In Hamburg, they were rarely out of each other's sight, day and night, for months on end. Certainly, their accommodation improved over their five visits, but the constant demands of this shoulder-to-shoulder existence both tested and confirmed the group's personal and professional relationships and, for Lennon and McCartney in particular, as lan MacDonald has written, »their close creative proximity generated the electric atmosphere of fraternal competition [...] and where they did collaborate the results were nearly always remarkable« (MacDonald 1994: 12). However, this development was gradual: an evolutionary rather than revolutionary change. Covers continued to provide the nucleus of their performances in Hamburg. For example, at the group's unsuccessful audition for Decca Records in January 1962 (later released as The Decca Tapes album) twelve of the fifteen songs recorded were cover versions, as were 28 of the 30 songs recorded at the Star-Club during their final visit to Hamburg in December 1962 (and later released on The Beatles Live At The Star-Club album).

Apart from its impact on the dynamics of their live act and the expansion in their songwriting, Hamburg was influential in one more crucial way. Liverpool in 1959 and 1960 boasted relatively few musical retailers, and those that were there carried a limited stock. When the Beatles left the UK for Germany in August 1960, they took with them little in the way of equipment. Publicity photographs of the group taken on stage at the Indra provide a reliable guide to their instrumentation. Andy Babiuk has summarised it as follows: 
»Lennon has his Hofner Club 40 guitar, and Harrison his Futurama, both of which are plugged into one amplifier (a Selmer Truvoice). McCartney is pictured playing a right-handed Rosetti Solid 7, which he's restrung to make it left-handed. Sutcliffe has his Hofner 333 Bass, plugged into a Watkins Westminster amplifier belonging to Best, who's standing behind his Premier drum set« (Babiuk 2001: 34).

Once they had moved to the Kaiserkeller, the Beatles - conscious of their promotion to a bigger and better venue - took advantage of the lessons learned from watching and talking to other musicians (including Tony Sheridan and Roy Young, both of whom played regularly with the Beatles) to acquire new items of equipment to supplement or replace their existing range. The first addition was Sutcliffe's purchase of a Les Paul GA-40 amplifier. Lennon quickly bought (on hire-purchase, from the Musikhaus Rotthoff in Schanzenstraße) a 1958 Rickenbacker 325 that remained his instrument of choice over the next four years for live shows and recordings, and also a Fender Deluxe amplifier. When the group made its second visit to Hamburg to appear at the Top Ten Club, McCartney ordered a left-handed Höfner $(500 / 1)$ >violin b bass from the Steinway shop in the city centre. Lennon's Rickenbacker and McCartney's Höfner became, for both men, trademark accessories that would be indelibly associated with them. As the group's status (and income) grew, more equipment was purchased, in Liverpool and London, but the choices made in Hamburg remained an essential, and distinctive, part of their musical identity. Pete Best has recalled:

»We used to mooch around Hamburg and find these little music stores that were locked away in side streets. We found that there was equipment in Hamburg which you couldn't get in Liverpool. For example, I bought some Zildjian cymbals over there, and you'd get back to Liverpool and people would say, >Where on earth did you get these? The same thing happened with the guitars. John saw this Rickenbacker [...] that was the one he came back with, and made everyone's head turn in Liverpool. People were like: >My God, we've never seen anything like that before« (Best in Babiuk 2001: 38).

In these four components - the form of performance (its pace, its shape, its trajectory); the content of performance (i.e. the songs); the means of performance (the equipment \& accessories); and the consumption of the performance (i.e. the club audiences) - the story of the Beatles was decisively and irrevocably altered by their experiences in Hamburg. These were the four related dimensions of their apprenticeship, which allowed the group to develop a practical understanding of the craft of performance. Or, to frame it in sociological terms, they constituted a stransformative dynamic that enabled the four or five enthusiastic youngsters from Liverpool to emerge as 
an accomplished, innovative and self-sufficient unit of musicians, composers and performers.

My focus has been on the crucial ways in which the Beatles' practical understandings of their performance - first of their shortcomings as performers, then as eager students of ways in which to transform their performance in the competitive and concentrated arena of Hamburg's clubs have been neglected. And consequently, I would argue that our understanding of the Beatles as performers has also been overshadowed by an overt attention to their later achievements as recording artists.

Perhaps, in conclusion, the comments of John Lennon (in words that echo Sarah Thornton's references to truth and authenticity) provide the clearest summary of the Beatles in Hamburg:

»We were performers in Hamburg, and what we generated was fantastic [...] there was nobody to touch us in Britain. But the edges were knocked off. Brian put us in suits and all that, and we made it very, very big. But we sold out, you know. The music was dead. We had to reduce an hour or two hours playing [...] to twenty minutes, and go on and repeat the same twenty minutes every night. The Beatles' music died then: we killed ourselves to make it. We always missed those dates, because that's when we were playing music« (Lennon in Wenner 1970: 45-46).

\section{Bibliography}

Babiuk, Andy (2000). Beatles Gear. San Francisco: Backbeat Books.

Beatles (2000). Anthology. London: Cassell.

Brocken, Mike (1996). "Some Other Guys! Some Theories About Signification:

Beatles Cover Versions. «In: Popular Music And Society 20:4, pp. 5-40.

Coleman, Ray (1995). McCartney: Yesterday And Today. London: Boxtree.

Davies, Hunter (1968). The Beatles. London: William Heinemann.

Giuliano, Geoffrey / Giuliano, Brenda (Eds.) (1995). The Lost Beatles Interviews. London: Virgin.

Gould, Jonathan (2007). Can't Buy Me Love. New York: Harmony. Jackson, Peter (1989). Maps Of Meaning. London: Routledge.

Leach, Sam (1999). The Rocking City. Gwynned: Pharaoh Press.

Leigh, Spencer (2004). Twist And Shout! Merseybeat, The Cavern, The Star-Club And The Beatles. Liverpool: Nirvana.

MacDonald, Ian (1994). Revolution In The Head: The Beatles Records And The Sixties. London: Fourth Estate.

Martin, George (1983). Making Music. London: Pan.

Miles, Barry (1997). Paul McCartney: Many Years From Now. London: Secker \& Warburg. 
Sharp, Ken (1997). »Jurgen Vollmer.«In Goldmine 451, 7 November, pp. $39-45$ (reprinted in The Beatles Digest. Ed. by Goldmine Magazine. Iola, WI: Krause 2000, pp. 39-45).

Sheff, David / Golson, G. Barry (1981). The Playboy Interviews With John Lennon \& Yoko Ono. New York: Playboy Press.

Spitz, Bob (2005). The Beatles. New York: Little Brown \& Co.

Sutcliffe, Pauline / Thompson, Douglas (2001). The Beatles Shadow: Stuart Sutcliffe And His Lonely Hearts Club. London: Sidgwick \& Jackson.

Thornton, Sarah (1995). Club Cultures. Cambridge: Polity.

Toynbee, Jason (2000). Making Popular Music. London: Arnold.

Wenner, Jann (1970). Lennon Remembers. New York: Penguin.

White, Avron Levine (1987). Lost In Music: Culture, Style And The Musical Event. London: Routledge.

Williams, Allan / Marshall, William (1975). The Man Who Gave The Beatles Away. London: Elm Tree.

\begin{abstract}
Although there is broad agreement about the importance of the Beatles' time in Hamburg, there have been relatively few sustained or detailed investigations of the causes, contexts and consequences of the changes that the city wrought in them. In approaching the topic, it is important to distinguish between the mundane reality of the Beatles and Hamburg as they were in the early 1960s, and the myths and legends that have grown up around them. While many accounts have been presented within a stereotyped mythology of "sex and drugs and rock'n'roll«, the real significance of the Beatles' experiences lies in their responses to the constraints and opportunities of live performance. A close analysis of the performative and related musical skills the group acquired during their club engagements in Hamburg will argue that it was here that four or five unemployed teenagers from Liverpool learned to be the Beatles.
\end{abstract}

